\title{
FOUR CASES OF TYMPANOSCLEROSIS
}

By

\author{
Tsutomu MATSUZAKI and MAsAyUki NAGAKURA
}

\section{From the Department of Oto-Rhino-Laryngology, Faculty of Medicine, University of Tokyo (Director: Prof. I. Kirikae)}

Four cases of tympanosclerosis were reported with ahistorical review of its literatures.

Two male and two female patients of less than 30 years old with chief complaints of otorrhoea and hearing loss were examined.

Surgery revealed main selerotic regions in the epitympanum and mastoid cavity.
Several types of tympanoplasty were performed on these cases.

Some clinical considerations on incidence, age and sex, clinical signs, audiogram, operation proce. dures and histopathological findings of tympanos. clerosis were discussed.

\section{鼓 室 硬 化 症 の 臨 床 的 観 察}

\section{東京大学医学部耳鼻㸶喉科学教室 (主任: 切替一郎教授)}

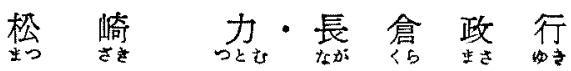

\section{I. 緒肻}

近年，鼓室成幵術の隆盛によつて，その術前及び術中 に鼓空腔内の病变像を詳緗に检钨し，正僬に把握すべき ことが要求されるよらになつた。そと結果として，豉室 内粘膜が著明に肥厚, 硬化し, 耳小骨の可動性を高度に 障害する病変が屡々報告されつつある。

この病変像小，必ずしも目新しいものではない，文献 的にも，既に前世紀後半に類似の記載がある。にめか わらず，それは恐らく，㑂音譏样修復術発展のここ半世 紀の過程に，部分的には㓋察されながらも，特別の注意

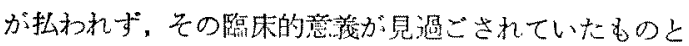

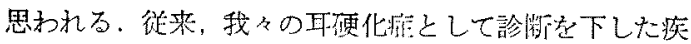

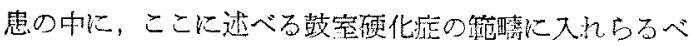

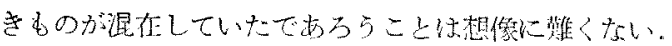

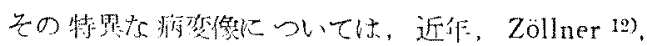
House ${ }^{16)}$, Harris ${ }^{18)}$, Joseph 21) らによつて “蚁空硬化

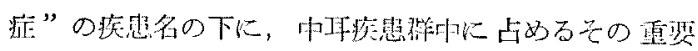

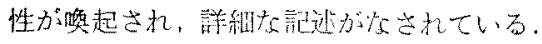

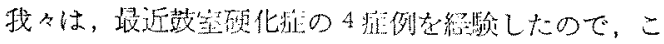
こにその文哃的考察を添光て翰告し，大方の御批判，御 教示を仰ぎたいと思う。

\section{II. 文献的考察}

鼓室硬化症の文薾的考察は Harris ${ }^{18)}$ の論文に和い

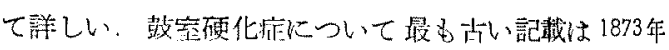
von Tröltsch 1) の著書に見出されるという，彼は“紣

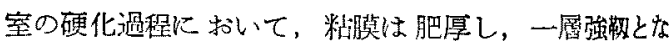
り，弹力性を失ならとていいには，石灰性，威性変

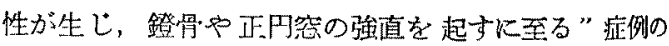
あることを述べている。この内容は，今日我々の鼓室硬 化症之呼ぶ疾㭧の病变像之一致するものと思われる。

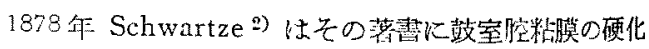

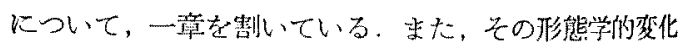

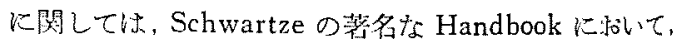
第1 频 (1892年) 飞 Habermann 3) 加，第2 版(1893

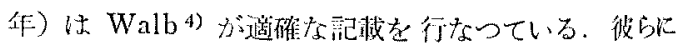

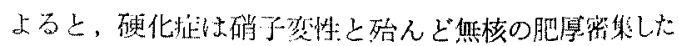

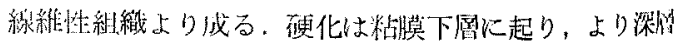

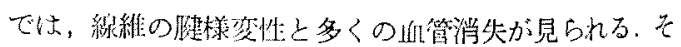

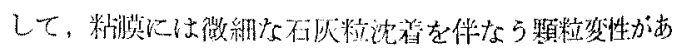

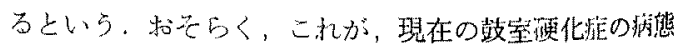
記述の最初のものと思加れる。特に Habermann ${ }^{3)}$ は

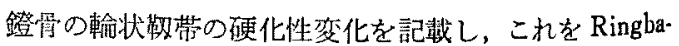


ndsklerose と呼称した.

その後 Winslow 5) (1882 年) は政室の慢性炎定性变 化の結果として, 亄室硬化症様の病的像を記し, Pomeroy 6)（1883 年）は Schwartze の著書を引用し，慢性 中耳カタルの病理について書いている.

St. John. Roosa 7)（1891 年）は鼓室硬化の病変中 耳の慢性非化膿性炎症の項の下に記している。 それによ ると，鼓室は乾懆して，殆んど分泌を胃ず，異常な被発 によつてのみ炎症活動を薏起する状態であるといら。

1894 年 Politzer ${ }^{8)}$ は中耳の “カタル性愈着性過程” の題の下に硬化症病峳の病理解剖学的变化を明らかにし ている.

今留紀に入つて, Brühl 9) (1923 年) 以鐙骨をを取纽ん で，耳小骨連鎖に強㨁を起している䓩䇪硬化性病変を慢 性カタルの項に和いて述べている。さらに1926年，彼

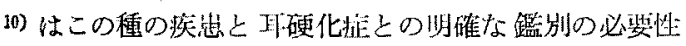

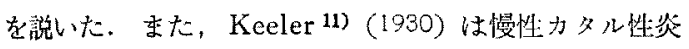
赫の硬化悲は hypertrophy よりししる hyperplasiaで むると編じている。

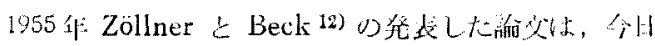
の “Paukensklerose” の名称が初めて登場したといら 意味ばかりでなく，画期的な策瞔であつた。この論文

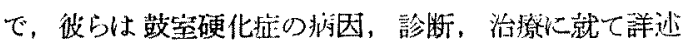

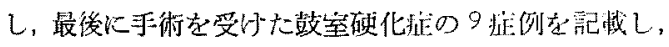

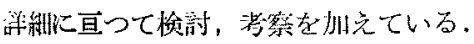

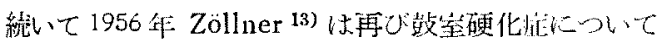

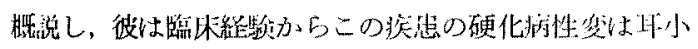

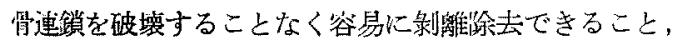
そして術後再発する傾问の見ら机奴ことといら二つの特

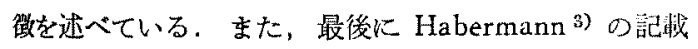
した Ringbandsklerose に相当すると思われる卵等简 を中心とする政室硬化症の一例を挙げ，その手術術式を 議述している.

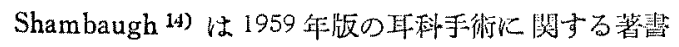
の中で，鼓室硬化症について，Zöllner 13) の論欢を引 用し、簡粱比言及している。

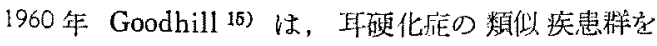
“Pseudo-otosclerosis”之総称し，耳手術老行な5园家

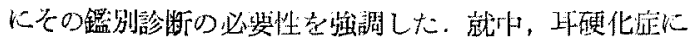

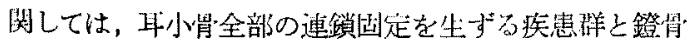

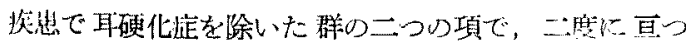

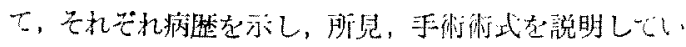
る.

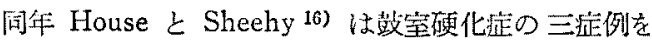
举げ，最大聴力回復のために，それぞれの症例に適応し た手術方法を記载した。また，彼らは攱空硬化症の病態

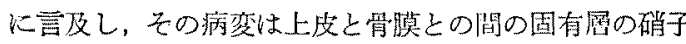

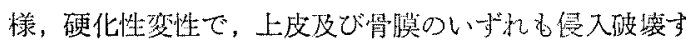
るものでないと諭じている。ざらに，既疾㭧と真珠腄及 び耳硬化症との鑑別点について詳述している。

1961 年 Brockman ${ }^{17)}$ は故室成形術に执いて，造通

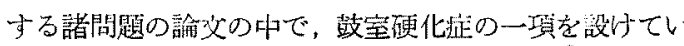
る.

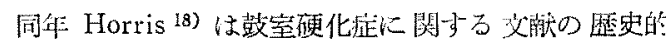

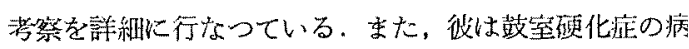
変に，正常粘膜と骨膜との間に存在与る從来の所謂良性

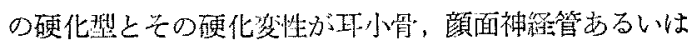
迷路骨胞などに浸入する浸潤型の二種類のある武を観察 L, 塑者莸 Sclerosing mucositis, 後者索 osteoclastic mucoperiostitis と呼称した，特に後者はZ Zöllner の論

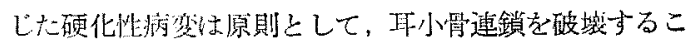

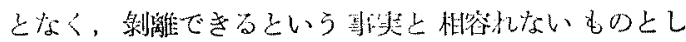

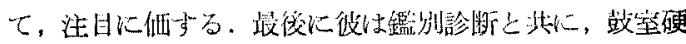

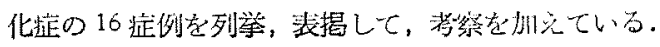

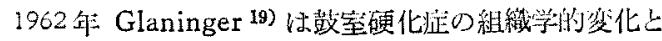

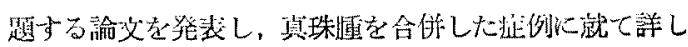
い银告を行なっている。

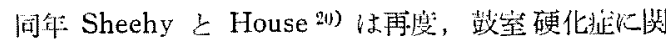

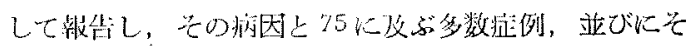

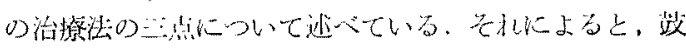
室硬化症は慢性中耳炎の約3 分の一に見られ，一般の慢

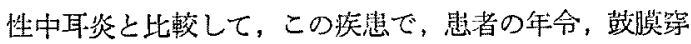
孔の型, 真珠連の存否, 手術結果江有無の差はなかつた と結諭している。

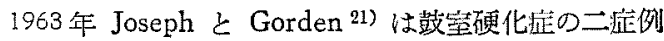
を郝告し，その手術術式として，一例は鐙骨を prosthesis で䟺撸する力法，他の一例は by-pass 法を試行し，

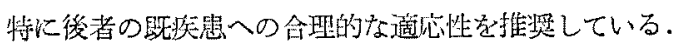

同年，Heermann 22) は次の上5\% by-pass 法学上政

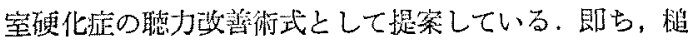

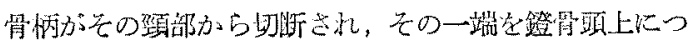

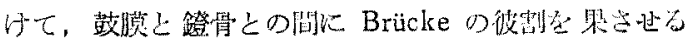
ものである。

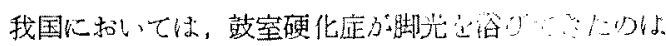
ここ数年のことにすぎない。

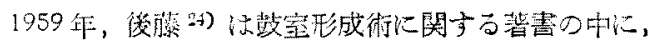




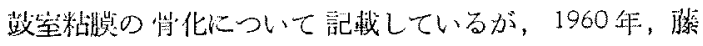
沢，伊藤 25) 恃著しき粘膜骨化伴なつた慢性中耳炎の

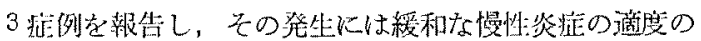

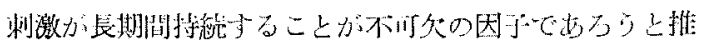
治している。

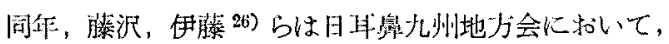
鼓室硬化淀について発表している。それによる之，1960

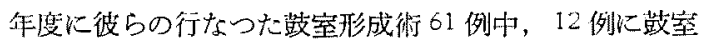
硬化が著明隹認められ，先の病態は鼓膜，鼓室粘膜，耳 小肖筇，腱の骨化西るい忧石死沈着から，耳小省関節強 直，骨性疮着化至るまでが観察されたという。

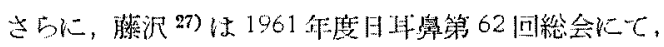
再度上記の症例について跟告し，手術力法は Wullstein

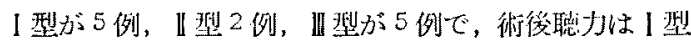

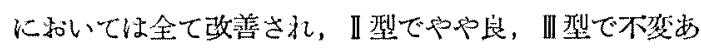
るいはやや良妃であったと述べた。

尔た同席上，以田 ${ }^{28)}$ らは，彼の外游見聞記と其に，

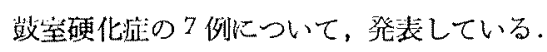

以上，交献的考察を要約与ると，哣室硬化症の歴史 は，1955 年 Zöllner の “Paukensklerosel” の名称の 嘴天となつた論文発琵に一期を画して，それ以前の慢性 瘾着性中耳炎の籍棝に包括されていた教科書的記載の時 代之，そ机以後の中耳伝音機構修復の課題の下に，それ ぞれの症例が詳細比検討されつつある時代とに大別され よう.

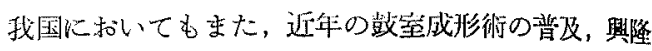
ともに，鼓室硬化淀の認識が高まり，本邦に和いて比 較的稀有之見られている耳硬化聇之刘照的に，普遍的疾

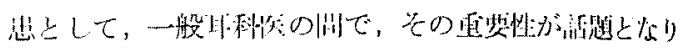
つつおる。

\section{III. 症例}

惟:例 1 .

患者： 22 才。 告于

主訴：画側難媤。左軽度耳漏。

初榕日 昭和 36 年 11 月 7 日

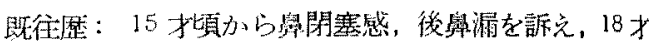

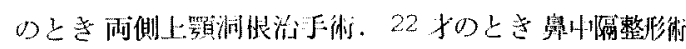
䔎受けた。

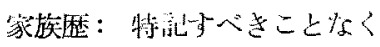

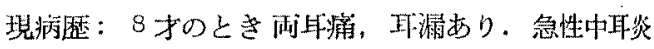
として耳科医の治㙩を受け，一将治猔したが，乙の後慢

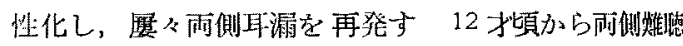

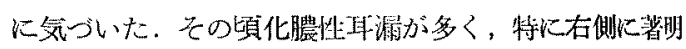
であつた。約 5 年前より两側の難䏇が急速に增琹したよ

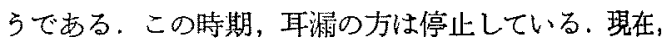
耳媳, 頭痛, 脑星はない。

現症：体格，栄養共に良好。

心㯖診にて前胸骨部に奔馬調律性心音を聴取する。血 圧 $128 / 70$.

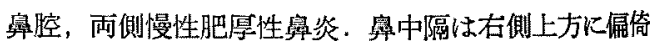

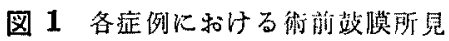

症 例 1

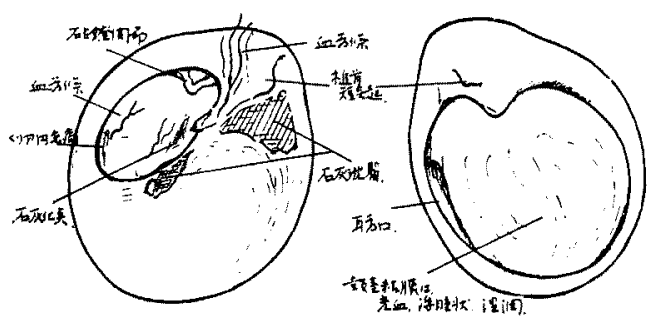

症 例 3

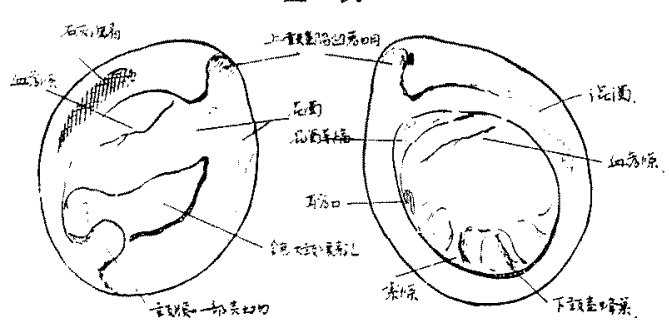

症 例 2

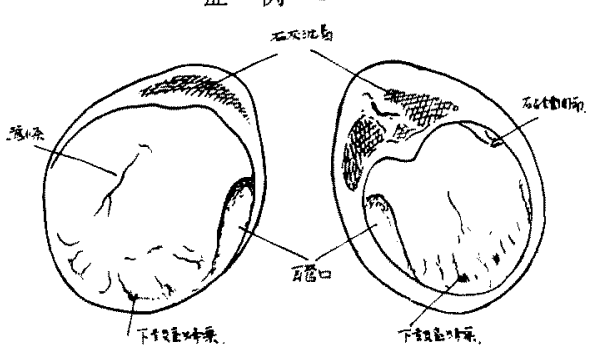

症 例 4

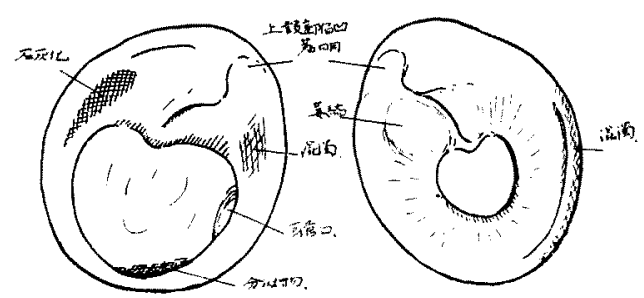




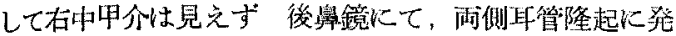
赤, 瘇脤を漶める。

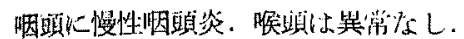

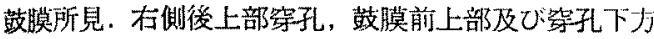

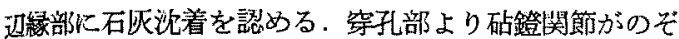
まれる将，との周边部には炎症症状は見られない，鼓室

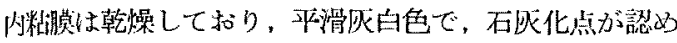

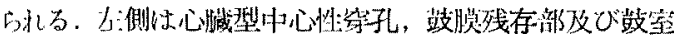

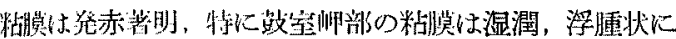
睡脸している（为1）。

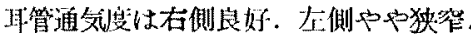

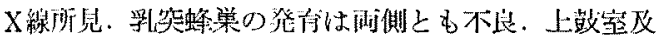

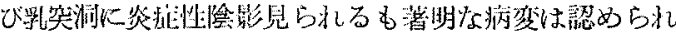

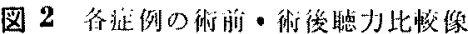

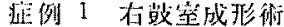
(I 型) 14 日目

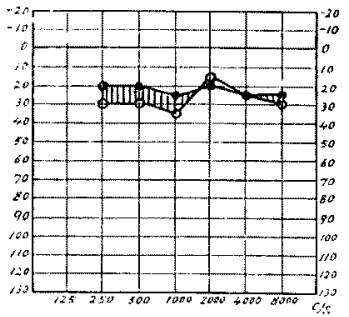

症例 2 左鼓室成形術 (II 䍿) 20 日目

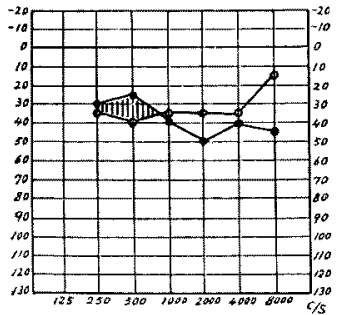

应例 3 石致空成形郝 (111 犁) 19 日目

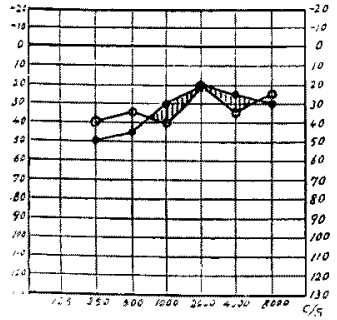

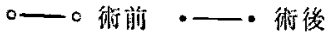

症例 2 右鼓室成形術 (II 型) 15 日目

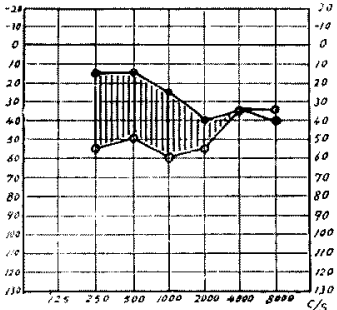

症例 4 右芠室成形術 (任琹) 12 日目

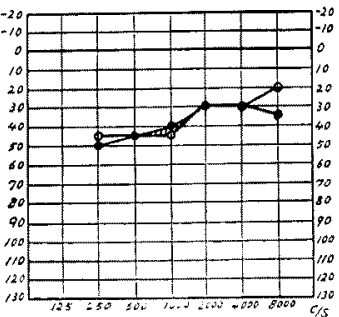

綎線は聴力改善を示す
*大

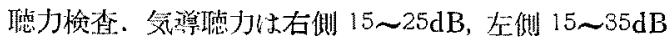

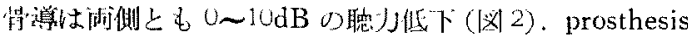

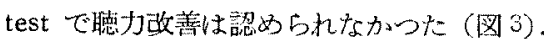

噪床榆查では血液像に異常なく，ワ民梅毒反忘陰性，

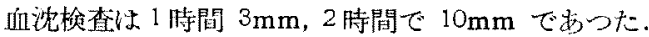

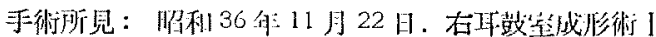

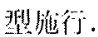

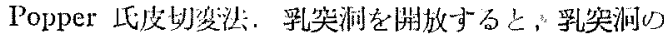

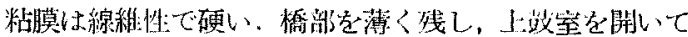

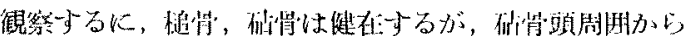

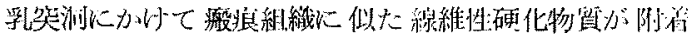

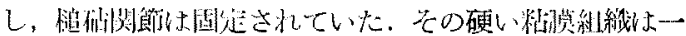

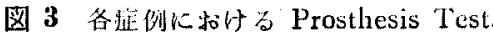
定例 1 有数跮䂵化庭

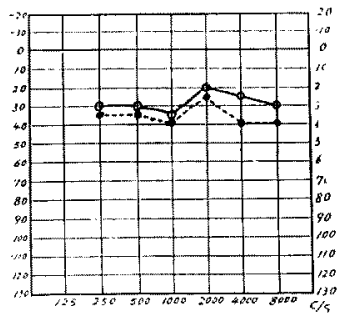

症例 2 左鼓室缏化症 症例 2 右鐓宝硬化症
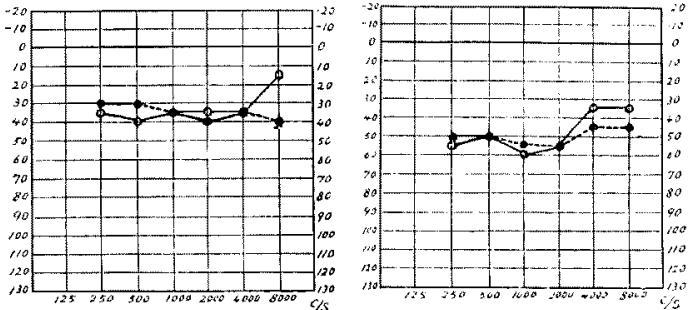

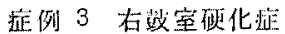

症例 4 在䟾空便化庭
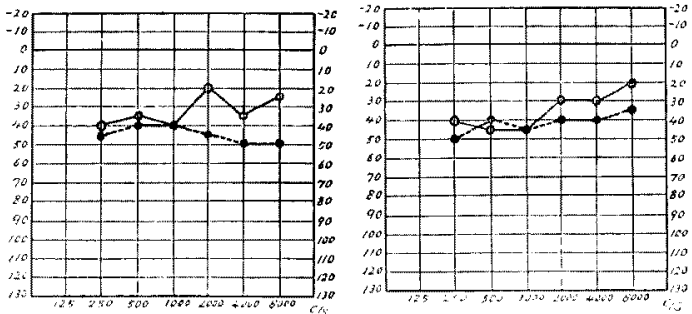

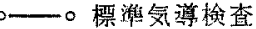

- Prosthesis Test. 
部㷟婴頭部にも密着してその可陲性を障害していた。鐙 骨及び卵円空窝には硬化性病变存在せず，砧鐙関節は梴 全で鐙育の可動性は正常であつた。耳顕微鏡下に強敬な

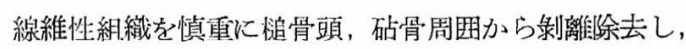
耳小筲を完全に可動性にした。外耳道, 鼓膜穿孔部, 上 鼓室, 乳突洞を一枚の遊離皮弁で被い, 手術終る（図 4).

\section{图 4} 症例 1 病变 図

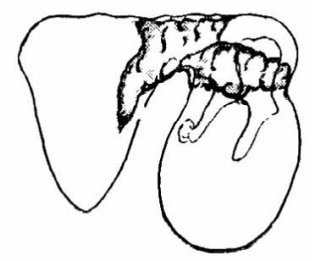

掠例 2 将贫划
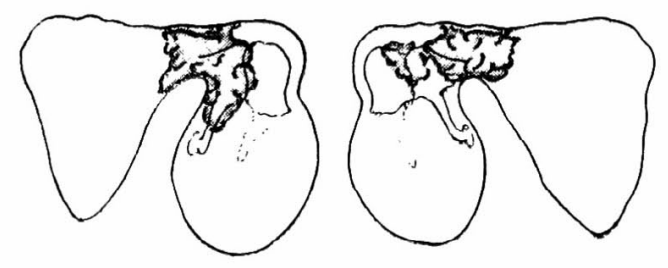

症例 3 抦资図 症例 4 将变図

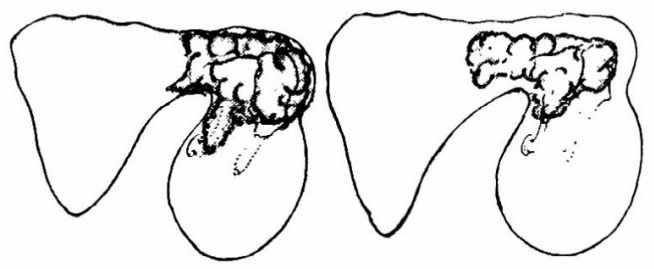

写 真 1

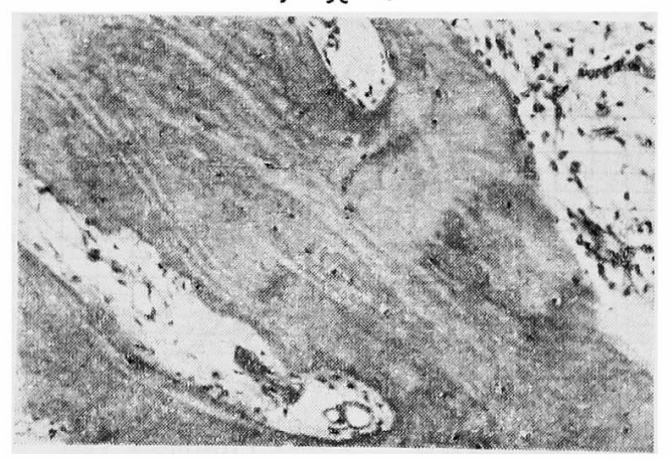

術後経過：経過良好にして, 昭和 36 年 12 月9 日退 院. 退院時乳突洞の一部に上皮化欠損あり肉芽を認む.

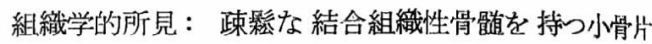
と，その骨脱面に概して層状を呈する角化硝子様物質加 ら成る。炎症性細胞の出現はない，本来の粘膜上皮は涊 め難い（写真 1).

\section{症例 2 .}

患者： 30 才，男子.

主訴：两側難聴, 耳膤, 耳鳴.

初診日昭和 37 年 3 月 3 日。

家族暦：特記すべきことなし，既往歴で幼封より風 邪に羅患し易く，鼻閉塞感あり.

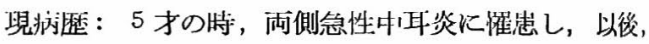
風邪をひくたびに両側耳漏を生ず．治療すると短期間に 治疮するが，容易に耳漏が 再発する．20才前後より， 雨聑鳴が始まり，疲労すると著しい。この頃から，雨耳 聴力が漸次低下している. 現在, 耳痛, 頭痛なく，全維 過を通じて，前庭症状は認めら机なからた。

現正：体格，栄養良原.

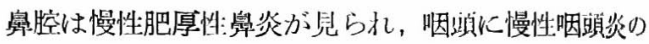
幽洑があつたが，堠頭には異常所見なし。

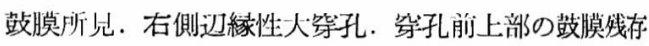

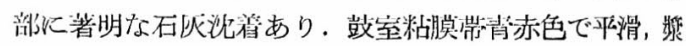

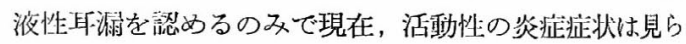
れない

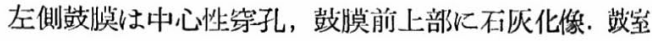

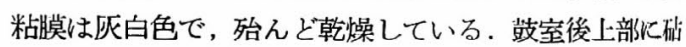
鐙関節の一部が観察される（図 1).

耳管通気度. 両側とも良好.

$\mathrm{X}$ 線所見. 両側共に乳突峰巣の発育不全. 左上鼓室に 硬化性陰影が認められるが, 真珠腫を疑がわしめる如き 骨破壊は見られない。

聴力众查. 気導聴力, 右側 20 30dB, 左側 35 60dB で骨導聴力は两側共にほぼ正常であつた（図2).

手術所胃：昭和 37 年 4 月 25 日，左鼓室 成形術 【 型 を施行.

Popper 氏皮切变法. 乳突洞開放術を行ならに, 乳乫 洞は弛緩した肉芽で充満されていたが，洞の内面の粘漠 は硬く，一部骨新生を認めた。上教室では，耳小削は硬 化性肉芽に理まれており、特汇砧骨の後方及び側方に， 灰白色やや带黄色の堅い限局性の物筫》゙固算していた。 これらの組織はメスにて容易に耳小骨から剝離できた が, 砧骨の後内方の線維性顿骨硬の板状物は剝济住囦難で 
あつた，啝骨柄は 欠損していたが，他の耳小骨は正常 で，砧鐙関節も健在することを確認した．鐙骨及び卵円 空窝には著明な病变なく、鼓室岬部，下鼓室さらに耳管 口にも異常見られなからた. 上豉室から乳突洞にかけて の硬化性組織を完全に剝離除去した後，肥厚した鼓膜残 存部は下縁を残して除去し, 遊離皮弁にて, 乳突洞, 上 散室, 耳小骨, 鼓膜欠損部を被つた（図 4).

昭和 37 年 5 月 22 日. 右亄室成形術 $I$ 型施行.

Popper 氏皮切变济: 乳突洞開放すると, 内面に骨新

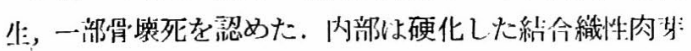
が存在した、上攱室では.耳.小骨の周用に灰白色硬化性板 状の肉芽の附着があり, 特に砧骨は硬化組織に上り埋 没，固定されていたが，メスと鉗子でほぼ完全に除去で きた。棺骨柄は存在せず，砧骨の後敬带も断裂して，白 色硬化像を是していた. しかし, 砧骨長脚は健在し, 砧 鐙関節は正常, 鐙骨及び卵円空窝には病变少なく, 鐙骨 はよく動いた，鼓室岬部，耳管口，下鼓室には特別な病 変は認められなかつた. 不灰化と著明な肥厚を示す残存 鼓膜を除去し，乳突洞，上鼓室鼓膜欠損部を遊離皮弁で 被つて手術を終了(図 4).

術後経過：術後，感染なく経過良好. 術後二週間に て左移植鼓膜に小穿孔を生じたが，マーキロ塗布療法に より，約 15 日間で閉鎖した。昭和 37 年 6 月 7 日退院.

退院時所見, 雨耳ともに乾燥している. 右外耳道後壁に 小さな肉芽を認めるのみ，移植皮弁はよく定着してい， る. 聴力像忙図の如く, 右側では 20〜 25dB の聴力增 加を示したが，左側では 15〜20 の聴力低下を起した. 両側とも，高音部は術後，聴力不变あるいは低下が見ら れた (図2).

組織学的所見:

左側. 扁平上皮が壊死様, 硝子様となり，それに著明

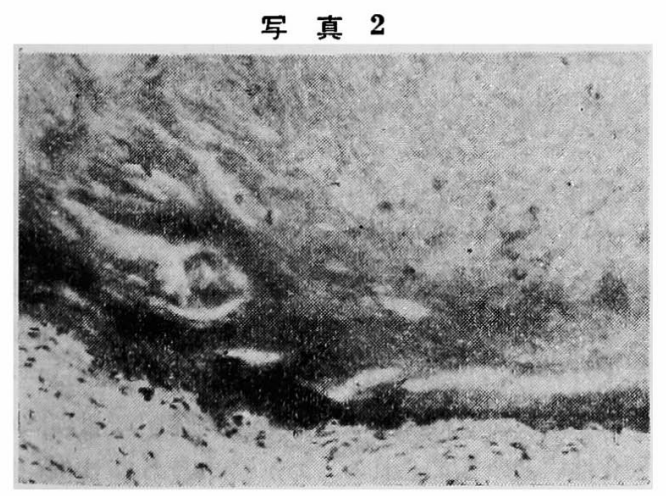

な石灰沈着が認められる，一部に基質が見られるが，約 維性となつて硬化肥厚している。

右側．リンパ球，プラスマ細胞，組織球の浸潤を伴な う慢性炎症を示す線維性組織で，一部硝子様变性を㺯 し，一部は血管に富んでいる.

組織学的診断. 両側鼓室粘膜の硬化性硝子様変性. 歺 性物質中に石灰化及び小骨化像を認む(写真 2).

症例 3 .

患著：21 才，女子

主:派: 雨側難聴, 左耳漏.

初部门：炤和 38 年 2 月 1 日。

既往暦及び家族暦：特記すべきことなし.

現病歴：生後間もなく右急性中耳炎に羅患，後慢性 中耳炎となり，風邪のたびに右耳漏が生じた。 13 才。 頃から右難聴に気づく１8才の時，左急性中耳炎より 慢性化し, 現在に至る迄, 耳漏を反復している。一方, 右耳漏は約 7 年前より停止して現在愁訴ない。

現症：体格pp小柄, 栄盖良好.

鼻腔. 両側慢性肥厚性奥炎.

咽頭. 慢性扁桃炎. 啒頭異常な乙.

鼓膜所見．右側鼓膜中心部に 錚状の不規則な穿孔を り，穿孔像は鈍に肥厚している. 鼓膜残存部に混濁及ひ 石灰沈着を認める，鼓膜後下部に篍粒大の表面平滑，堅 く上皮化された突出物が見られる。鼓室内は灰白色半透 明の粘膜で被われ，乾燥している。

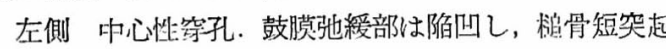

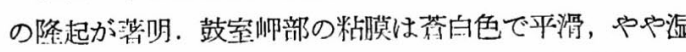

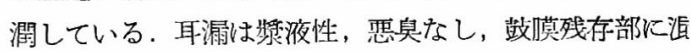
罢あり(図 1).

耳管通気度. 右側良好. 左側规窄音あり.

X線所見. 孚突蜂巣の発育は右側で完全に抑制され， 左側は中や不良，骨硬化あるいは骨破壊像等は特に認女 なからた。

聴力検查. 気導㯖力は右側 $20 \sim 40 \mathrm{~dB}$, 左側は 10 46 $d B$, 骨導は正常 (図 2). prosthesis test では聴力改善 は認められなかつた（因了）.

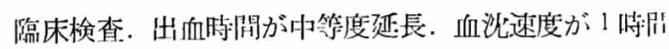

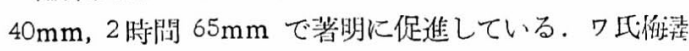
反応陰性.

手術所見：昭和 38 年 3 月 18 日，右跂室成形術四型 施行.

Popper 氏皮切变法. 先ず上政室を開放するに，上彭 室は灰白色硬化性の組織で充満し，鋭题でかくとボロオ 


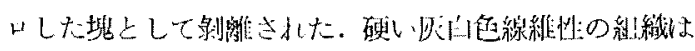
概骨頭及び砧骨頭を被い，さらに後方に延びて砧骨の長 脚部位を包み，一部は乳突洞に及んでいた，耳小骨に固 论した硬化性粘膜を慎重に剩離して見ると，柜骨柄及び 砧骨の長脚は消失して，砧鐙関簛は完全に離断してい， た。しかしながら鐙骨開团，卵阘登窝には硬化性病変見 られず，鐙骨の可動性は保たれていた。梪骨及び砧骨を

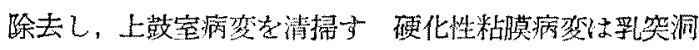

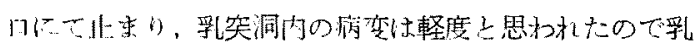

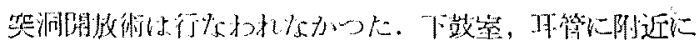

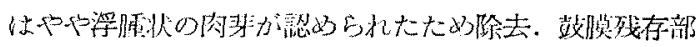
は㤝度に肥厚し，硬化していたのですべて除き，遊倠皮 并を鐙骨頭に密着させ，上鼓室及び鼓室を被うように植 皮した（図 4)。

術後経過：術後経過は良好で，炤和37年4.月8 日退 院. 退院時, 外耳道前上壁に少量の肉芽組織を認める が，鼓膜は上く定着し，分泌物少ない，退院時聴力検查

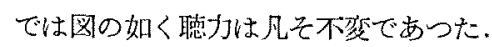

組織学的所見：扁可上皮化した 粘膜の下圆に肥厚し た線維性組蟣が見られる。一部殆儿ど均質な硝子様变性 あり，徽細な石厕顆粒の沈着を認める。

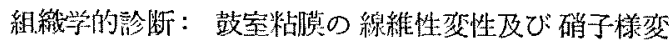
坚.

瘕例 4.

患者：20才，多子

主部: 両側難㜇。耳漏.

初熵日炤和 38 年 8 月 28 日。

既往昰及び家族歴：特記すべきことなし，

现病歷：2才の時から雨側慢性中耳焱上なる，以後，

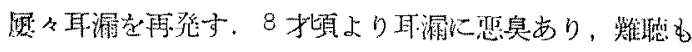

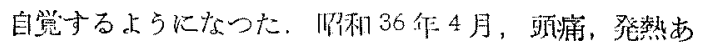
り，脂膜炎を疑がわれた，10日间位 $40^{\circ} \mathrm{C}$ の発熱が続

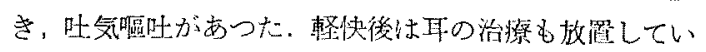
る.4勾前より難悖が進行して, 現在, 補聴器を侹用し ている.

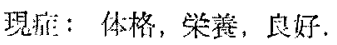

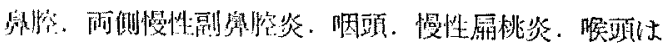

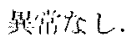

敋膜所見. 右側中心性大第孔. 做膜残存部前上方に混 濁，後上方に石灰沈着を認む，穿孔上縁から桘骨柄に沿

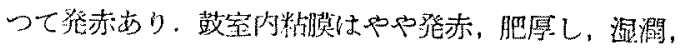

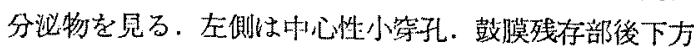
に混滛，穿孔上緑はやや糜熼性肉莱様である。鼓膜粘膜

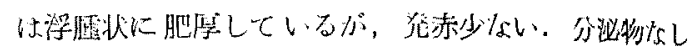
(図 1).

耳管通気度，啊側飞狭窄音あり。

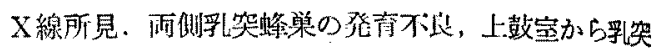
洞水江て资症性硬化像を見る。

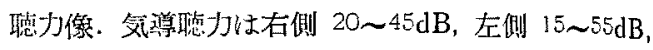

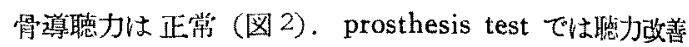
は認めら机なかった（因了）。

臨床検查では血液像に異常なく、ワ氏梅毒反応陰性で

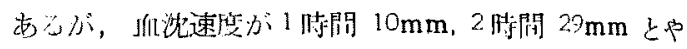
中促進している。

手術所見：

炤和 38 年9月 20 日。敬室成形術 III 型施行.

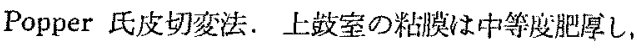
薈白，耳小骨に固く疮着，乳突洞口には小豆大白色塊

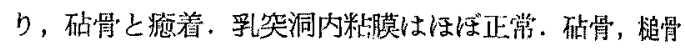
の頭部内側は硬化性組織に 埋没されていた。鹤骨，砧 骨，鐙骨は非常に萎縮性ではあつたが存在した，砧鎖関 節は坐症性粘膜で被われていたが，連鎖は睢断してい

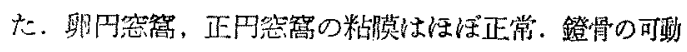
性保存されていた，砧骨，粮骨を上鼓室の硬化性病変と

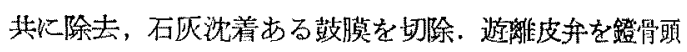
にのせるように移植して手術終る(図4)。

組織学的診断：豉室粘膜の硬化硝子様变性

\section{IV. 紷括及び考按}

前項において，我々は最近経駼した政室硬化泟の 4 例 について報告した，次にそれらの症例に関して，諸文䙲 に見られる従来の報告と比較檢討を加えてみたい。

(1) 発生浻度

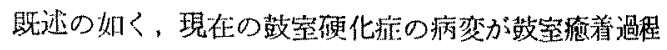
として記载されて以来，紾一世紀の藏月が経過してい る.が，その間，耳硬化症之の鑑別はある程度なされつ

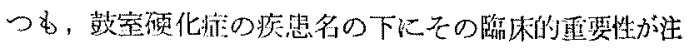
日を浴びてきたのは，近々10年に满たない，

Paukensklerose の命名者 Zöllner ${ }^{12)}$ はこの疾患の 頻度には言及していないが，Harris ${ }^{18)}$ は乳突洞炎を伴 な5慢性叶联 310 例中 16 例 (約 5\%) 飞 Sheeny ${ }^{20)}$ は慢性 中平桨の 227 例中 75 例（約 $33 \%$ ）に数室硬化症 が見出されると報告している，ま大本邦においては，藤

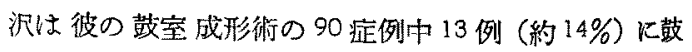
音硬化の著明な病变を認めたといら。なお Sheehy 201 の報告に見られる高頻度は，彼の75症例中，散膜汇の 子硬化性病变の諮められるものが約半数の 38 症例它 
表 1 教 室硬 化症 症例

\begin{tabular}{|c|c|c|c|c|c|c|c|c|c|c|c|c|}
\hline 豈年 & 性 & 主 訴 & 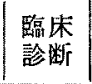 & 病 歴 & 做膜所見 & 穿 孔 & 噑室所見 & $\mathrm{X}$ 線像所見 & 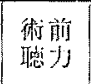 & 手㹯 術 式 & 術後 & 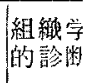 \\
\hline \multirow{2}{*}{$\left.1\right|^{22}$} & \multirow{2}{*}{$\begin{array}{l}\text { 男 } \\
\text { 子 }\end{array}$} & \multirow{2}{*}{$\begin{array}{l}\text { 両侧難聴 } \\
\text { 左側耳漏 }\end{array}$} & \multirow{2}{*}{\begin{tabular}{|} 
雨慢性 \\
化膿性 \\
中耳炎
\end{tabular}} & \multirow{2}{*}{$\begin{array}{l}8 \text { オのと } \\
\text { きから }\end{array}$} & $\begin{array}{l}\text { 右肥曆不 } \\
\text { 側|灰沈着| }\end{array}$ & $\begin{array}{l}\text { 俊上部 } \\
\text { 中心性 } \\
\text { 穿子 }\end{array}$ & \begin{tabular}{|l|} 
平消灰白色 \\
乾燥
\end{tabular} & 下策 & $35 \mathrm{~dB}$ & 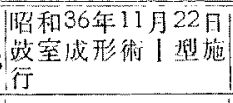 & $20 \sim \mathrm{dB}$ & $\begin{array}{l}\text { 教室做 } \\
\text { 化進 }\end{array}$ \\
\hline & & & & & 告 登 利 & $\begin{array}{l}\text { 中心性 } \\
\text { 大䄀孔 }\end{array}$ & $\mid$ & & $15 \widetilde{d}$ & & & \\
\hline \multirow[b]{2}{*}{2} & \multirow{2}{*}{$\begin{array}{l}\text { 舁 } \\
\text { 于 }\end{array}$} & \multirow{2}{*}{ 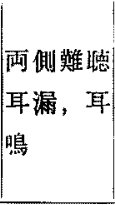 } & \multirow{2}{*}{$\mid \begin{array}{l}\text { 两慢性 } \\
\text { 化䁸性 } \\
\text { 中耳炎 }\end{array}$} & \multirow{2}{*}{$\begin{array}{l}5 \neq 0< \\
z か 5\end{array}$} & $\begin{array}{l}\text { 存石灰沈 } \\
\text { 側着 }\end{array}$ & $\begin{array}{l}\text { 癹程性 } \\
\text { 大穿孔 }\end{array}$ & 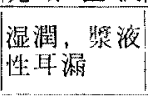 & 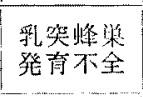 & $30 \mathrm{~dB}$ & 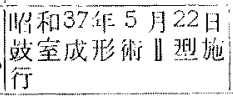 & $50 \mathrm{~dB}$ & 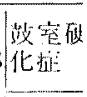 \\
\hline & & & & & $\begin{array}{l}\text { 㔯石死沈 } \\
\text { 側着 }\end{array}$ & $\begin{array}{l}\text { 中心湠 } \\
\text { 穿孔 }\end{array}$ & | & 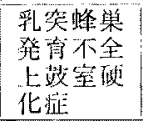 & $6 \widetilde{0 d B}$ & 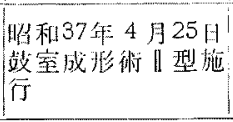 & $45 \mathrm{~dB}$ & 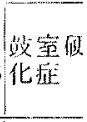 \\
\hline \multirow{2}{*}{$\left.3\right|^{21}$} & \multirow{2}{*}{$\frac{b}{7}$} & \multirow{2}{*}{ 雨侧難㯖 } & \multirow{2}{*}{$\mid \begin{array}{l}\text { 両慢性 } \\
\text { 化腄性 } \\
\text { 中耳㷋 }\end{array}$} & \multirow{2}{*}{ 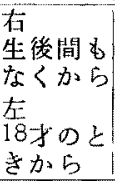 } & 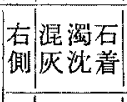 & $\begin{array}{l}\text { 鐡状口 } \\
\text { 中心性 } \\
\text { 案我 }\end{array}$ & 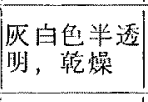 & 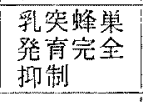 & $40 \mathrm{~dB}$ & 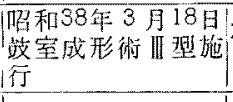 & $50 \sim \mathrm{dB}$ & 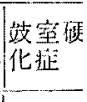 \\
\hline & & & & & $\left|\frac{x}{x}\right|$ & $\begin{array}{l}\text { 中心情: } \\
\text { 穿孔 }\end{array}$ & $\mid$ & 樂 & $\mid 10 \widetilde{40 d B}$ & & & \\
\hline \multirow{2}{*}{4} & \multirow{2}{*}{ 女 } & \multirow{2}{*}{$\mid \begin{array}{l}\text { 两側難聴 } \\
\text { 望漏 }\end{array}$} & \multirow{2}{*}{ 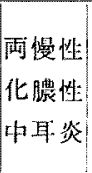 } & \multirow{2}{*}{$\begin{array}{l}2 \text { オちと } \\
\text { हわ口 }\end{array}$} & 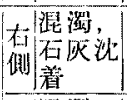 & $\begin{array}{l}\text { 中心弪 } \\
\text { 大等孔 }\end{array}$ & $\begin{array}{l}\text { 䉼膜肥曆 } \\
\text { 笓赤湿潤 }\end{array}$ & $\begin{array}{l}\text { 乳突峰笨 } \\
\text { 等青不全 }\end{array}$ & $45 \mathrm{~dB}$ & 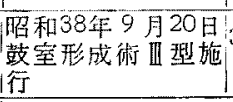 & $50 \sim$ & 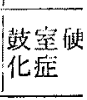 \\
\hline & & & & & 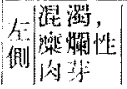 & 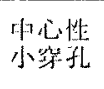 & 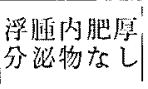 & 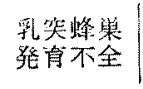 & $\frac{15}{55 \mathrm{~dB}}$ & & & \\
\hline
\end{tabular}

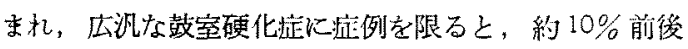
の頻度となる、以上の報告より，一般耳鼻科矤を訪九る 慢性中耳炎の約 5 10\% 亿故空硬化症が存在するものと 推企さ机る，近年の鼓室硬化症の出現頻度の增加小，鼓 空成班術の発展もさることながら，術中の耳顕徽鏡の応

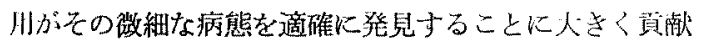

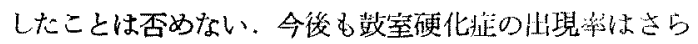
に增州することが予想される。

\section{[I] 年令と性别}

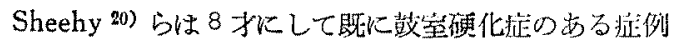

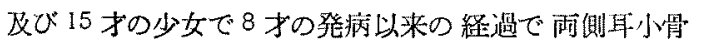
連鎖の完全固定を有した症例を 報告している。一力， Harris ${ }^{18)}$ は彼の 310 症例中 66 例は小見の耳疾䍐であ つたが小見には鼓室硬化症は全く見出せなかつたと述へ ている.この Harris ${ }^{18)}$ の報告は鼓室硬化症の発病以 来, その病像の完成に通常 10〜15 年の経過党 要するこ とを暗示するるのであるら。

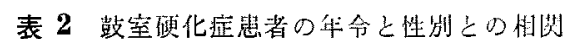

\begin{tabular}{|c|c|c|c|c|c|c|c|}
\hline 性㣍年命 & 10 代 & 20 代 & 30 代 & 40 代 & 50 代 & 60代 & 合計 $(\%)$ \\
\hline 男 性: & 4 & 6 & 5 & 2 & 1 & 0 & $18(40 \%)$ \\
\hline 奴 性 & 1 & 7 & 7 & 3 & 8 & 1 & $27(60 \%)$ \\
\hline
\end{tabular}

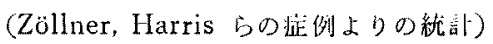

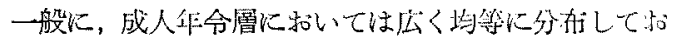

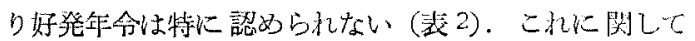

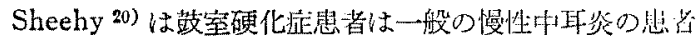
に比し，年令的に特別の意議を見出さなかつたと述べて いるが，藤沢 27) 5も彼の15 の症例で同様の結果を得 ている。

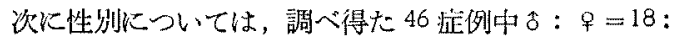
27 で女性にやや多い㑯向が見られた。市た年令と性別 との相関では女性にやや高命者の多いことが楒められた (表了).

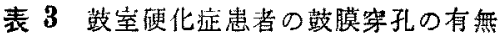

\begin{tabular}{|c|c|c|c|c|c|c|c|}
\hline 膜所兒 & $\begin{array}{l}\text { Zollner } \\
\& \text { Beck }\end{array}$ & $\begin{array}{l}\text { House } \\
\& \text { Sheehy }\end{array}$ & \begin{tabular}{|l|} 
Joseph \\
$\&$ Gorden
\end{tabular} & Harris & $\begin{array}{l}\text { Sheehy } \\
\& \text { House }\end{array}$ & 我々の鿊例 & 合計 $(\%)$ \\
\hline 数膜学孔和り & 8 & 3 & $\therefore$ & 13 & 60 & 5 & $97(89 \%)$ \\
\hline 改膜䄰孔な L & 1 & 0 & 0 & 3 & 9 & 0 & $13(11,0)$ \\
\hline
\end{tabular}


我々の症例では男 2 名, 女 2 名で, 20 代 3 名, 30 代 1 名の内別で共に比較的若年者であつた。

\section{(II) 病因}

Zöllner ${ }^{12)}$ らは 鼓室硬化掟をして一般慢性化膘性中 耳炎が辿る最終段階の一亜型と考え，その病因としてア レルギー性素因を想定している，その証拠に，彼らは鼓 室硬化症の患者の多くに皮腐あるいは粘膜において䓵麻

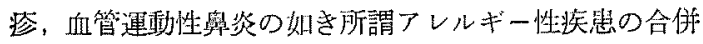
を認めたといら。李た，その数例において，血液中及び 病理組織中に好酸性顆粒細胞の著明な增加を倠察したと 述べている。しかしながら，Harris ${ }^{18)}$ は彼の16症例 のすべての病理組織灲好酸性顆粒細肪の出現が証明され なかつたと報告して拈り，山田らも，その7症例全部に アレルギー性素因を認めなからたと発表している，我々

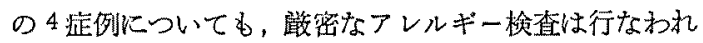
なからたが，家族歴，既往歴にその素因となる疾患を見 出せなからた。

以上，要するに靖室硬化症の発生には，一般炎怔に刘 する特暴な組織没応の根底上なるある誘因，素因の存在 が，当然推測されるとこちであるが，現在のところ，そ の明確な結論は得られていないようである。

[V]現 病魔

“好少時に，急性中耳炎家以て発淤し，以後，慢性中 耳炎の状態で絟過し, 時折, 短期間の耳漏を反復する. しかも气の耳漏性粉末乾懆療法の如きすので急速に停止 する，そして 10〜15 年の経過中，徐々ではあるが進行 性に伝音系難聴が起つてくる”この記載は諸文献中の 現病歴の項㳊しく一致して見出されるものである。こ の簡単な絟過つららに緩徐ながらも，着实に，正常粘膜

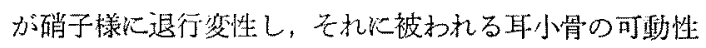
を次第に制約しつつある病变像が矮知される。

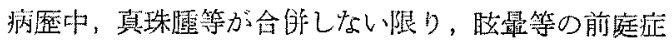
状は見ら机いいが通常であるが，Harris ${ }^{18)}$ 忧彼の所 謂鼓空碛化症の“Invasive type”で矓最を主訴とする

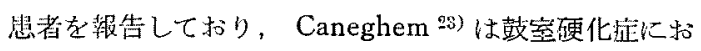
いて，迷路拉状も中耳挍变とほぼ平行して起り，その原

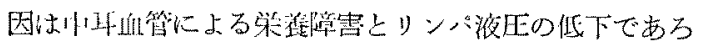
ら上考察している。

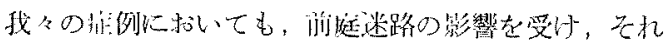

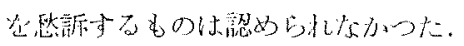

\section{(V) 現 症}

鼓謿所胃。

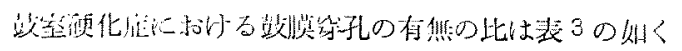

である。

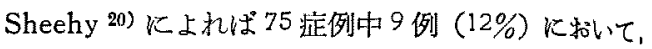
鼓膜の穿孔が認められなかつたといら。このような拝例 では鼓膜の石灰沈着の存否が，唯一の診断上の手億り之 なり，耳鏡所見による診断を一酋困難にする。. Sheehy 20) はこの疾患の約 $80 \%$ に鼓膜の硬化症が見られると述

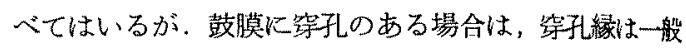
に肥厚して㧍り，多くの場合乾燥した鼓室粘膜は平滑で 象牙色を呈し肥厚している. 鼓膜穿孔の型に関しては, Sheehy 20) は中心泾穿孔が 50\%，辺縁性穿孔が 38\%で あつたと報告し，一般の慢性中耳炎のそれと有意の差梳 ないと述べている。

我々の症例では，全例に鼓膜穿孔があり，そのらち一 耳は辺緑性の大穿孔であつた。

$\mathrm{X}$ 線所見.

幼小児期に発病するために乳㔖蜂巣の発育が抑制され た症例が多い，上鼓室の病変は硬化像が著明であると記 载されている文献もあるが，一般の炎症性変化のそれと の鑑別山難しい上らに思われる、特に真珠尰様の陰影が 認められる場合は，真珠尰症の診断が下され，術中に初

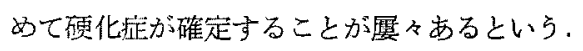

聴力像 (図 5)

図 5 敞室硬化堽の㯖力像
我々の症例

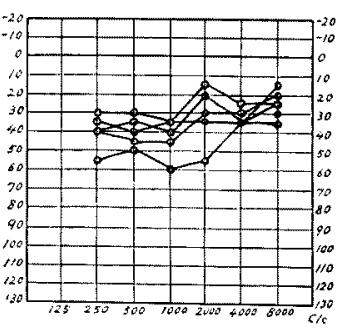

Zöllner の 19 症例上り

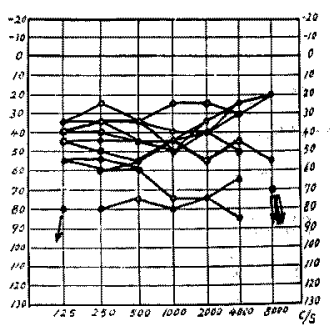

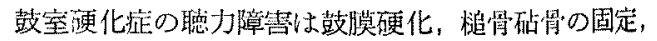
また蹬骨正円空卵円空の可動性障害によつて生ずる，従 つてこの疾患の㯖力像は，典型的な伝音系難聴である.

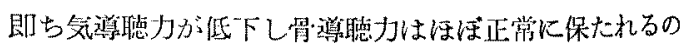

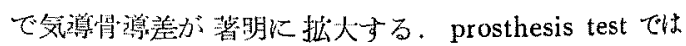

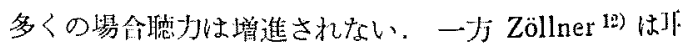

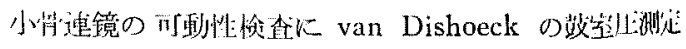
江とGellé 氏多法とを推楚している。

(11) 診 断

特微们な現病䓧，宫度の混濁，石灰沈着を示す故脱所 


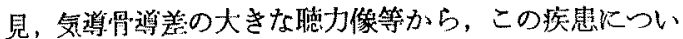
てある标度の予想はされるものの，確定診断は手術所見 及び病理組織学的検查に頼られねね゙ならない 奏際，敨

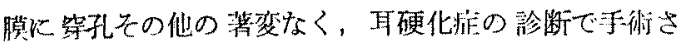

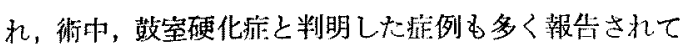
いる. 我々の症例に関しては全例飞幸にして鼓膜穿孔， 石灰沈着等の比較的明らかな所見が認められたので，衍

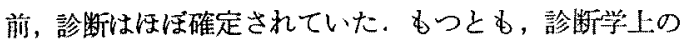
重要さは術前のそれでなく，術中の方針決定に際しての

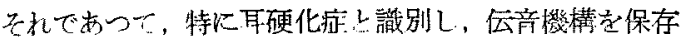

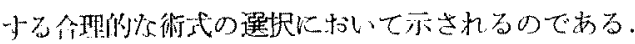

鼓䇪硬化症の鑑別診断化関しては Goodhill 15) が Pseudootosclerosis の概念の下に示した詳しい諭交があ る。次汽れを列挙して見る。

\section{I 全耳小骨連鎖固定}

A. 癒着性線維化を伴なう慢性膠質耳疾患, B. 肉莱

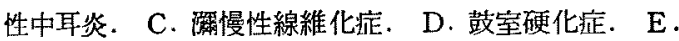
耳小骨連鎖の沉筲関節炎.

II砧骨疾患
A. 砧骨の外傷性脱曰.
B. 砧骨固定。
C. 砧骨篓

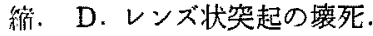

\section{III鐙骨の非耳硬化应性疾患}

A. ペーヂエット氏狱． B. 骨形成不全症．Ｃ. 鼓 室硬化症．Ｄ．鐙骨板関節炎． E. 鐙骨周团天幕， F 先天性固定.

N 耳再小骨と沺・正円空の奇形

しかしながら，儖床的に最も鑑別を必要とする疾患は 耳硬化症と真珠遮症であるう。

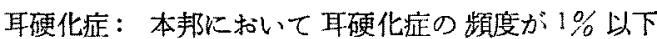
の極めて稀有の疾患であるのに対し，鼓室硬化症は前述 の如く，屡々観察されるものである，病歴では女子にや や多く，奸娠等の誘园が見られることがある．散膜所見 は正常であるのが特徵であるに比べ鼓室硬化症では第孔

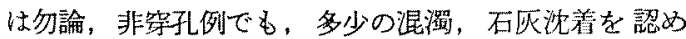
る。聴力像では殆儿ど鑑別できないが Gellé 氏法によ り，鼓室硬化症で鐙骨が固定されていない限り異なつた 維果を示寸

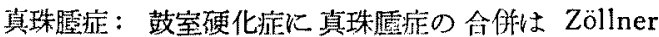
12) は9 例中 1 例, Sheehy ${ }^{20)}$ は 75 例中 21 例, Harris 18) は 16 例中 2 例をな藤沢 ${ }^{27)}$ は 15 例中 2 例を報告し

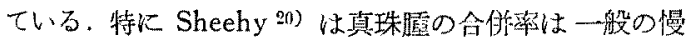
性中耳炎に拊けるそれに，有意の美がなからたと述べて

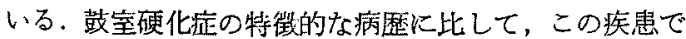

は持続性，碩固な留臭ある耳漏に悩まされる。鼓室内可 見で白色不定形の物質が観察されるときは，視診のみな

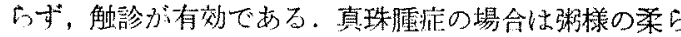

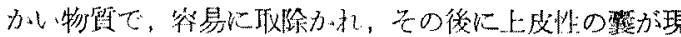
わ礼る。また，上鼓室洗㴪によつても簡単に清掃され る．X線所見では，著明な真珠灀㢈考除いて，これのみ て鑑别䛦断小難かしい。

VII 治療

保存的療法：鼓室硬化症は慢性化呩性中耳炎の最終 段階であるといら大方の見解を反映する如く，その患耳

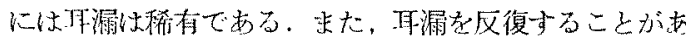

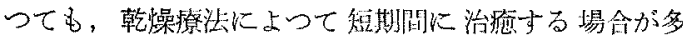
W.

根治療法：耳漏を一㭙的に停止させることができて も，その進行する伝音采難聴在改善するためには，その 病変を取除く手術的療法が必要である．特にその硬化性 組織が耳小骨運鎖を破堙することなく摘出できることを 特徽とするこの疾患では，讋断が確定次第，手術的療法 は先ず絶対の適応といえ上う，次炕ての術式の選択方針 を諸文献から考察略記して見る。

（i）吱膜に第孔の認められない場合

鼓膜に混濁，石灰沈着等が観察され，跂室硬化佂が疑 がわれるときは，試験的炕敋室を開放してみる。

(ii) 鼓膜に穿孔ある場合

二段階の 手術が House 10) らによつて姓掑されてい る. 即ち，一次的に鼓膜形成術を行ない，聴力改善のた めの硬化組織の除去怔二次的手術として行ならものであ る。それは polyethylene の支柱を新鮮な移植皮弁にあ てることは皮全の壊死が高頻度に見られること，また鉋 骨板老除去寸る際は内耳が直接污染領域に露比すること を予防する意味がある。

a ）鼓膜に石灰沈着のある場合

必ずしる，それらを取除くことは要しないが，石灰斑 が厚く大きく，下鼓室や耳管鼓室に突出して鼓膜の振動 を障害する場合，また，前上部に存在し，桘骨の可動性 を障䨐すると思われる場会は取除かれれねばならない。

石灰斑は鼓償線維摆に存在するので，上皮層あるい、 综孔縁に切開を入れて，取出すことは容易である。この 際，線維層はできるだけ保存するのがよい，

b ）栕骨，砧骨が硬化總織で固定されている場合 硬化組織它慎重に虽離除去することが大切である。多 くの場合，耳小骨連鎖機棒を健在の屯末，取除くことが

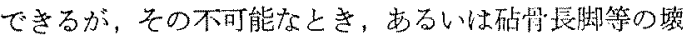
死欠椇で，砧鐙関節が中絶している場合は，梢骨柎をそ の輕部で町断し，鐙骨頭にのせる方法が考案されてい 


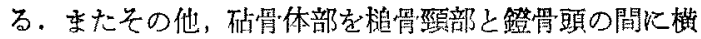
たわる上うに回転させる方法，あるいは切断した枨管柄 と鐙骨頭との間にポリエチレン管で by-pass する方法 等が工夫創案されている。

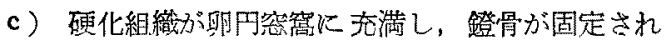
ている場合

この場合も，卵円突窝から微小なか針とメスとをもつて

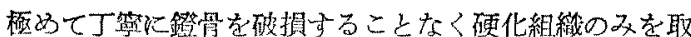
除くことは可能である。しかしながら，所謂 Ringbandsklerose あるい性円空筬から硬化性塊を除去でき

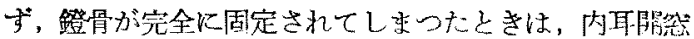
術を適応させ极ばならない。

Zöllner は鼓室成形術 III術を試みて術後聇力回復の見 られない患者に二次的に閔空術を施行し，聴力改善を認 めた二症例を報告している。

d）鼓膜張筋，鐙骨筋斿るいは耳小骨の龩带に石灰 沈着を起し，その機能を失なつている場合は各筋や腱を 切断し，鼓膜，耳小骨の可動性老確保する。

e）以上すべての場合に真珠堙症が 合㴊したときは 真珠腫の病樂を完全に清掃することが先決である，乙か るに後に伝音機構の修復術を検討寸る。

以上，要するに，中耳伍音機檴を障害する硬化珄物筫 を可及的に除去することによつて，耳小骨の楼能的連鎖 を保存, 回復さ好ることが鼓室硬化症の手術法の根本原 則である。

\section{V. 結語}

最近経験した鼓室硬化症 4 例について文献的考察を加 克て報告した。

1) 男女各 2 例ずつで，すべて 30 才以下であつた。 全症例汇怙いて 10 年以上の慢性化膿性中耳焱の病歴を 持っていた。

2）主訴は難聴，耳漏で，聴力検查で気導はほぼ 30 〜0dB の聴力損失を示したが，骨譐は大体正常であり た.

3）手術的療法として 鼓室成形術 I 型 (1 例)， I 型

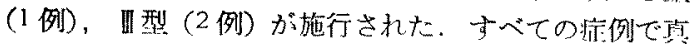
珠腫の合併は認められなかつた。

4）組織学的には战莫下層の硝子樣変性，不灰沈着を 基盤として多様な病変像を是していた。

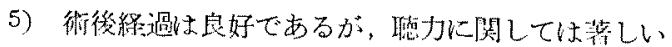
改善はみらら九なからた。

\section{文献}

1) Von Tröltsch, A.F.: Handbuch der OhrenheiIkunde. Leipzig. 1873

2) Schwartze, H.: The Pathological Anatomy of the Ear. Hirschwald, Berlin, Aug., 1878. 3) Habermann, J.: Handbuch der Ohrenheilkunde., H. Schwartze, I. Band, 1892.
4) Walb, H.: Handbuch der Ohrenheilkunde., H. Schwartze, 2. Band, 1893. 5) Winslow, W.H.:

The Human Ear and Its Diseases. 1882 . 6) Pomeroy, Oren D.: The Diagnosis and Treatment of Diseases of the Ear. Bermingham \& Co., 1883, 7) St. John Roosa, D.B.: A Practical Treatise on Diseases of the Ear, 1891. 18$)$ Politzer, A.: A Textbook of the Diseases of the Ear and Adjacent Organs. Lea Brothers \& Co., $1894 . \quad$ 9) Brühl, G.: Lehrbuch und Atlas der Ohrenheilkunde J.F. Lehmanns Verlag, München. 1923. 10) Brühl. G.: Handbuch Denker-Kahler VII. Springer-Berg. mann, Berlin-München, 1926. 11) Keeler, J.C.: Modern Otology. F.A. Davis Do. 1930.12 12) Zol. lner, F. and Beck, C.: Die Paukensklerose. Z. Laryng. Reinol. Otol., 34: 137 155, 1955. Zöllner, F.: Tympanosclerosis. J. Laryng., \& Otol $70: 77 \sim 85,1956 . \quad$ 14) Shambaugh, G.E., Jr: Surgery of the Ear. Saunders, Philadelphia, 1959. 15) Goodhill, V.: Pseudo-Otosclerosis. Laryngosco. pe, 70: 722 757, 1960. 16) House, W.F. and Sheehy, J.L.: Tympanosclerosis. Arch. Otolaryng. 72:308 313, 1960. 17) Brockman, S.T.: Problem Encountered in Tympanoplastic Surgery. Laryngos. cope. 71: 859 866, 1961. 18) Harris, L.: Tympanosclerosis- A Revived Clinicopathologic Entity. Laryngoscope $71: 1488 \sim 1533,1961.19)$ Glanin. ger, J.: Zur Histologie der Paukeusklerose. Acta Otolaryng. 55: 157 162, 1962. 20) Sheehy, J.L. and House, W.F.: Tympanosclerosis. Arch. Otola. ryng. 74: 151 152, $1962 . \quad 21)$ Joseph, R B. and Gorden, J.: Tympanosclerosis. Arch. Otolaryng, 77 : 186 190, 1963. 22) Heermann, J.: Syndes. mosen bei Paukensklerose. Acta. Otolaryng. 56:1 10, 1963. 23) Caneghem, D.v.: La deviation de la tête en position de Romberg dans la tympanosclérose. Acta. Otolaryng. 50: $301 \sim 308,1959.24$ ) 後藤修二：後藤式鼓室成形術，金原出版，1959，25) 藤呮康武，伊藤正夫：著しき粘膜骨化を伴なつた慢性

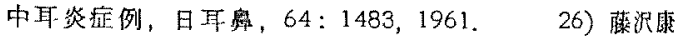
武：“Tympanosclerosis” Kついて, 日耳耳, 64: 1641，1961，27) 藤沢康武：䟾室硬化症 (Tympan-

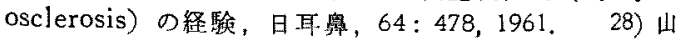

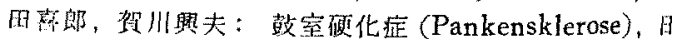
耳舅，64: 476〜477、1961. 29) 藤沢康武：Tympa-

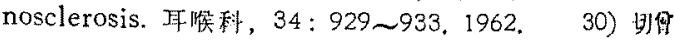

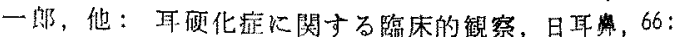
$1041 \sim 1049,1963$.

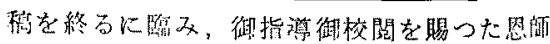
切简一郎教授に澡譤致します

（原槁到着=昭和 39.2.19日） 